\title{
Recent Status of Banteng (Bos javanicus) Conservation in East Java and Its Perspectives on Ecotourism Planning
}

Luchman Hakim $^{1 *}$, Dodit Ari Guntoro ${ }^{2}$, Joko Waluyo ${ }^{3}$, Dian Sulastini ${ }^{4}$, Lugi Hartanto ${ }^{4}$, Nokukazu Nakagoshi $^{5}$

\author{
${ }^{1}$ Department of Biology, Faculty of Mathematics and Natural Sciences, University of Brawijaya, Indonesia \\ ${ }^{2}$ Meru Betiri National Park, Jl. Sriwijaya 53, Jember, East Java, Indonesia \\ ${ }^{3}$ Baluran National Park, Bantangan, Sitobondo, East Java, Indonesia \\ ${ }^{4}$ Alas Purwo National Park, Jl. Brawijaya, Banyuwangi, East Java, Indonesia \\ ${ }^{5}$ Graduate School for International Development and Cooperation, Higashi-Hiroshima, Hiroshima, Japan
}

\section{ABSTRACT}

The aims of this article are to examine the recent status of Banteng Bos javanicus conservation in East Java, identify the roots of conservation problems and propose the non-consumptive and sustainable uses of Banteng by implementing ecotourism. Recently, Banteng population distributes in Alas Purwo, Meru Betiri, and Balu ran National Parks. The population in Alas Purwo and Meru Betiri were relatively stable yearly. Rapid population decrease found in Baluran National Park. The roots of threats may be categorized into two factors, socio-economic and ecological factors. Socio-economic problems lead to the increase of habitat disturbance, poaching, and illegal hunting. Ecological aspect was ranging from invasion of exotic plant species, competitors, predators, drought, forest fire and vegetation changes. Lack of habitat management also recognized as an important factor to drive Bos javanicus decline and extinction. Ecotourism in the national park may become one of the significant and effective stimuli to support Banteng conservation.

Keywords: banteng Bos javanicus, conservation, East Java, population threats, tourism

\section{INTRODUCTION}

Banteng Bos javanicus d'Alton is an endangered animal in the world, which naturally distribute from northern India and Burma to Borneo, Java, and Bali. In Java, historical documents were shown that previous distribution was found almost the whole area of Java. However, vast industrialization, rapid human population growth, and forest disturbance affect Banteng, and other wildlife become isolated and fragmented in the several remaining forest patch at Java Island. Recently, Banteng distributes at the west part (administratively are Banten and West Java Province) and the eastern part (East Java Province) of the island. In West Java, the main habitat of Banteng are Ujung Kulon National Park, Cikepuh, and Leuweng Sancang, while in East Java this species was found at Meru Betiri National Park, Baluran National Park (BNP) and Alas Purwo National Park (APNP) [1,2].

\footnotetext{
${ }^{*}$ Corresponding author:

Luchman Hakim

Department of Biology, Faculty of Mathematics and Natural

Sciences, University of Brawijaya, Indonesia

E-mail: luchman@ub.ac.id
}

Morphologically, the male and female species are in different features. The male species has black skin, and the female has mid-brown skin. Both male and female have white stockings on the lower legs. Banteng ranges from 190 to $225 \mathrm{~cm}$ in total body length, and the average of height is $160 \mathrm{~cm}$. The activities of the species are the diurnal type, means there are no discriminate between days and night in term of activity. However, in the area where human disturbance occurs, Banteng become nocturnal or active in the night. Sexual maturity at 2-3 years, and the live span of Banteng is about 20 years. There is only one adult male in each herd, but sometimes 2-3 male occurs in a herd in Sadengan feeding area of APNP [2,3]. Naturally, Banteng distributes at savanna, shrub, and lowland forests. It indicated that there are no preferred habitat of Banteng, it depending on suitable food as the main factor of home area at the Park $[2,4]$.

In Java, the establishment of protected area system has seems allow species conserved in natural habitat, but several documents show that Banteng conservation in the serious problem [5,6]. Whitten et al., [2] state that the population of Banteng in Java may be not far- 
ing badly, but Pudyatmoko [7] in his report argues that Banteng populations in Java heavily threaten. Following the recent conditions of Banteng conservation in East Java, it seems that encourage harmonious relationships between people and their environments were urgently needed to conceptualize. Its means that sustainable uses of natural resources should be promoted as a way to conserve Banteng as well as other wildlife in the national park. The key issues and strategy to meet economic development and biodiversity conservation in balance should be developed, and wildlife tourism seems become one of the ways to achieve its objectives. Wildlife tourism is tourism type that ultimately related to tourist experience to wildlife in natural habitat.

Integrating wildlife into tourism industry has been becoming one of the tools to conserve wildlife and support economic growth [8,9]. Higginbottom et al., [10] argues that the benefits of wildlife tourism for conservations are numerous, encompasses (1) attention to animals will increasing, particularly in wildlife management practices and research, (2) providing finding support for wildlife conservation, (3) allowing education for conservation, (4) enhancing political will to support biodiversity conservation, and (5) serving socio-economic incentives for conservation. Those promises seem to be a win-win solution for economic growth and conservation purposes, and allowing sustainable uses of natural resources.

In this paper, we examine the current condition of Banteng at three national parks, namely Baluran $\mathrm{Na}-$ tional Park (BNP), Meru Betiri National Park (MBNP) and Alas Purwo National Park (APNP) at East Java. Discussion based on the archival studies and fieldwork. In particular, interviews techniques was applied to determine the perception of park's ranger and local people perception to Banteng in tourism programs development. Based on research finding, we describe the recent status of Banteng conservation, identify the roots of conservation threats, and propose sustainable uses of Banteng and its habitat by implementing sustainable tourism.

\section{MATERIALS AND METHODS}

In order to elicit a vivid picture of Banteng conservation in East Java as a basis for its conservation planning, a review of the recent conservation status was needed. It becomes crucial for the next step due to Banteng conservation information were lack, unstructured filed, distribute patchily among offices, and there were lack of integrative assessment. For this reason, three national park offices were visited to collect information related Banteng conservation programs. National park documents and reports both published and unpublished were reviewed. Materials are also collected research report were collected from university, institute and conservation agency.

A field survey was carried out at APNP, MBNP and BNP during 2011-2013 The close relationship between author and key persons of parks led in-depth interviews method possibly to apply. This method allowing face-to-face interaction between interviewers and respondents, and provide a chance to learn how the authorities of parks reflect their opinion on Banteng, argues the official conservation effort strategy, and generate their perception into future conservation effort. The interviews with the main person (i.e.: head national parks, head of parks sections, rangers, local people) were carried out to drawn comprehensive information about Banteng conservation and tourism programs and development.

In essence, the questionnaire survey was designed to seek the status of encounter wildlife activity in the park, particularly Banteng as a tourism object. SWOT analysis was conducted to draws the strategy of the use of Banteng as natural tourism object in a national park. Descriptive information about the strengths, weaknesses, opportunities and threats of the uses of Banteng as a natural object for nature-based tourism attraction was obtained by the uses of several statement questionnaire.

\section{RESULTS AND DISCUSSION \\ Recent Status of Banteng conservation at East Java}

The history of Banteng Bos javanicus conservation in East Java may date back to the Dutch colonial era. In 1929, the attention to the Banteng conservation as well as other Javan wildlife had promoted by Dammerman. He states that hunting of wildlife has threats to Java wildlife, and Netherlands East Indies government should initiate the policy to manage such activities [11]. The best population of Banteng in East Java has reported by F.J. Appelman in 1937 at Baluran. Following the scholar's recommendation, and due to wildlife richness, the area has declared as protected forest at 1930 and redesigned as 'wild reservaat' in 1937 [12]. Furthermore, the area was declared as national park in1980. Recently, the populations of Banteng in East Java are conserved in three national park, Baluran National Park (25,000 ha.), Alas Purwo National Park (42,000 ha.), and Meru Betiri National Park (58,000 ha.). 


\section{Banteng in Baluran National Park}

In the past, the data of Banteng population was scare due to lack of periodic censuses. Before 1980's, Banteng in BNP was found Talpat, Bekol, Bama, Sirontoh, and Semiang. During 1990-2000, there is no Banteng population found in Talpat, Bama, and Sirontoh. In these periods, Banteng in BNP found in Bekol, Kelor, Semiang. The periods of 2000-2010, Banteng found in Kramat, Bekol, Bama, Kelor, Nyamplung, and Popongan. The result of population simulation analysis shows that Banteng population in Baluran National Park estimated the decrease in the future and will be extinct within 35 years due to the high mortality rate of juveniles. Water availability and food quality was reported as an important factors driving population movement. At BNP, Banteng uses only about one-third of the park as the main habitat. It seems that human disturbance, unsuitable vegetation and bovid competitors such as domestic cattle and feral buffalo are become the limiting factors for Banteng distribution within the park [2]. In 2011, there is about 22 individual was found and in 2012, there are about 26 individual was found in Bekol, Panjaitan, Nyampulung and Palongan.

The mature individuals have threatened by illegal hunting. It is also state that wild $\operatorname{dog}$ Cuon alpinus has predicted become the important predator of Banteng and lead population decrease [7]. The main threat to Banteng's habitat is come from alien plants species invasion. In 1969, Acacia nilotica was introduced to Baluran National Park as firebreak vegetation. The species are continuous to spread vigorously and replace native savannas vegetation. The seed production of Acacia nilotica was high, up to 175,000 seeds/tree and it is become a potential agent for species expansion [13]. Various methods have been tried to combat $A$. nilotica expansion such as uprooting, seedling removing, cutting tree, and applying chemical agents such herbicide. Although it is intensively applied to remove $A$. nilotica, the species still grow rapidly and become the main threat for Bekol savanna as Banteng habitat.

\section{Banteng in Alas Purwo National Park}

In other regions in East Java, Banteng distributes at APNP. The national park cover 42.000 ha and comprises several ecosystems such as mangroves forest, savanna, and lowland deciduous forest. The trees found in Alas Purwo are Ficus spp., Eugenia spp., Sterculia foetida, Kleinhovia hospita, Terminalia catappa, Langerstroemia flos-reginae, Tetrameles nudiflora and Eugenia spp., Vitex pubescent, and Manilkara kauki.
The management policy to conserve wildlife at APNP was conducted by establishing Sadengan feeding area (SFA), mainly to conserve Banteng. The feeding area was opened at 1971, and several kinds of grass species were planted with the objective is improving SFA quality as wildlife habitat and tourism destination in the park. Grasses and herbs consist of Arudinella setosa, Alysicarpus vaginalis, Cyperus brevivolius, C. iria, Dischantium caricosum, Eleusine indica, Fimbristylis sp., Andropogon contortus, Ischaeum sp, Panicum repens, Paspalum conjugatum, P. vaginatum and Polytrias amaura [4]. The population of Banteng in APNP are less known, but some scholars argue that previous number of Banteng at SFA may reach 100 individuals $[12,14]$. However, after 30 years, the vegetation structure is change. Alien species such as Lantana camara, Euphatorium inulifolium, and Cassia tora was dominant and alter vegetation structure. Such situation lead number of Banteng in SFA was known decrease [4]. The comprehensive assessment of Banteng population in Alas Purwo was absent. The population monitoring in 2012 in SFA shows that the averages number of Banteng visits SFA was ranged about $3-5$ individual per days. In May 2012, about 120 individual was recorded visit SFA. The total observed individually in 2011 in SFA was about 930 individual and increase 1.210 individuals in 2012 [15].

Since SFA is the main tourist destination of APNP, as well as the symbols for Banteng conservation, some strategies to improve SFA quality has applied by national park authorities. One is invasive plant species clearing effort using cutting machine, particularly to remove $E$. inulifolium and C. tora. However, the methods not effective since the species still growth and abundance in SFA. Chemical treatment using herbicide has been proposed, but it is very expensive and no budget available. In addition to that, there was no environmental impact assessment studies its implementation.

\section{Banteng in Meru Betiri National Park}

In Meru Betiri National Park, Banteng population was found in Sumbersari atas, Treblasala, Sumberayu, Pringtali, Malangsari, Pal IV, Nanggelan, and Pagar Gunung $[16,17]$. Banteng was also reported distributes at plantation area, namely PT. Perkebunan Sukamade Baru and PT. Perkebunan Bandealit. The population principally found in area with rich grasses and water resources. Hanberia [18] found that Banteng distribute at some rivers such as Sumbersari, Cawang, Sanen Kali and Banyuputih. 
Some species such as Paspalum conjugatum, Erechtites valerianifolia and Cyperus rotundus grows in Printali feeding ground. Some grasses and herbs such as Axonophus compressus, Hierochloe horsfieldii, Erechtites valerianifolia and Paspalum conjugatum were abundande in Bandealit plantation and becomes the important food source for Banteng [16]. Conflict between human and Banteng often occurs when Banteng uses plantation area as grazing habitats.

\section{Threats to Banteng in National Parks}

While Bos javanicus has been protected by national park establishment, it may be concluded that Banteng conservation under serious threat, and potentially initiate species extinction. Understanding the roots of threats is a prerequisite to determining the future strategy for conservation. The roots of threats may be categorized into two factors, socio-economic and ecological factors.

According to respondents, the impact of Indonesia economic crisis has serious impact on Indonesia economic. Based on statistical data, in 1998 Indonesian GDP decline by 13.1 percent and inflation increased to $58.5 \%$. The crisis had a deleterious effect on family income and unemployment rate increase. Among the consequences of the economic crisis have affected poverty increase from $11 \%$ in 1996 to $14-20 \%$ in 1998. Rural dweller has affected seriously and forest clearing by farmer increase significantly [19]. It is followed by illegal hunting, and Banteng has become the animals target of its activity to meet food source as reported by national park staffs. In Indonesia, the evidence of wildlife attack to crop has reported, and most researcher argues that insufficient foot number for wildlife be the main motivation wildlife goes to the rural agricultural systems [2,20]. Official reports show that Banteng in APNP become the animal target of il-

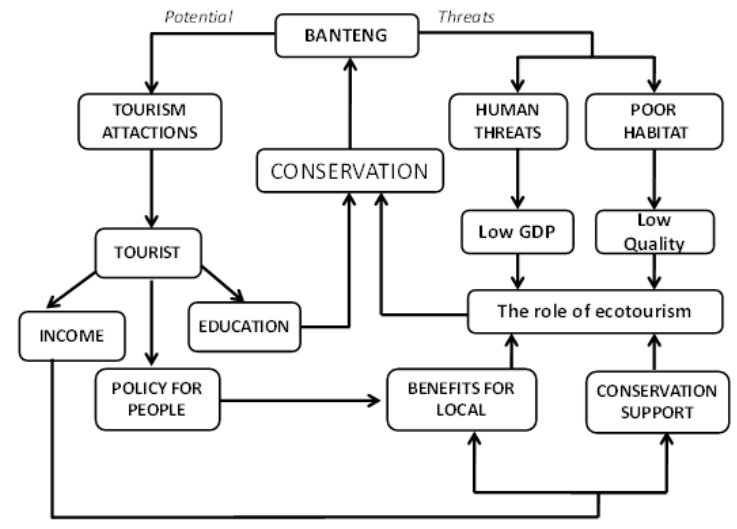

Figure 1. The contribution of tourism in Banteng population conservation.

legal poaching. National parks staffs state that poaching mostly occur in the buffer zone of the national park by establishing traditional traps.

Ecologically, serious threats to Banteng come from a competitor, predators, and decreasing habitat quality. For instance, feral buffalo and domestic cattle's of local dwellers has been recognized as serious competitor for Banteng in BNP since the animals assumed to compete Banteng for drinking water and grazing [2]. Illegal posturing has been occupied 2,000 ha of the park, particularly in Karang Tekok, Labuhan Merak, Kajang and Balanan [21]. Furthermore, Pudyatmoko [7] state that predation by Cuon alpinus increased for the last years in BNP and led Banteng population decrease. In APNP, Hedges and Thyson [14] argues that such predation by Cuon alpinus declined the Banteng population. Cuon alpinus is probably the most important predatory in both Baluran and Alas Purwo, but there are insufficient data of Cuon alpinus number to state the species responsible for the Banteng extinction [4]. With the extinction of Tiger from Java,

Table 1. SWOT analysis for ecotourism with banteng as flagship species.

\begin{tabular}{|c|c|c|}
\hline Aspect related Banteng & $\begin{array}{l}\text { Strengths } \\
\text { - Mega-charismatic species } \\
\text { - Native species to Java }\end{array}$ & $\begin{array}{l}\text { Weaknesses } \\
\text { - Vulnerable to human intrusion } \\
\text { - Ineffective conservation strategy }\end{array}$ \\
\hline $\begin{array}{l}\text { OPportamities } \\
\text { - Increase of ecotourism market } \\
\text { - Increase of comnunity awareness }\end{array}$ & $\begin{array}{l}\text { - Strengthening Banteng as tourism icon } \\
\text { - Using biodiversity crisis issues to grow } \\
\text { community awareness }\end{array}$ & $\begin{array}{l}\text { - Segmenting ecotourisn research markets and } \\
\text { strengthening responsible visitors managennent }\end{array}$ \\
\hline $\begin{array}{l}\text { Threats } \\
\text { - Tourist behavior } \\
\text { - Population decrease }\end{array}$ & $\begin{array}{l}\text { - Designing carrying capacity and tourist code of } \\
\text { conduct in wildlife tourisn } \\
\text { - Developing technology that area able to } \\
\text { increase population }\end{array}$ & $\begin{array}{l}\text { - Developing mechanism of tourist-wildlife } \\
\text { interaction in wild habitat }\end{array}$ \\
\hline
\end{tabular}


the leopard is probably the only large predator that regularly preys on Banteng.

Decreasing habitat was caused by forest fire, forest clearing and lack of management. Forest clearing lead to species roaming disturbance, insufficient food availability, reproductive isolation, and a fragmented population. Hakim et al., [4] shows that Banteng intensively uses the young leaf of Bambusa bambos that abundance in Sadengan. Unfortunately, many bamboo clump has illegally harvested by local people. The evidence of poor management by national park authorities come from some study by Alikondra and Hakim et al., [4,13]. Mostly, alien species invasion disturbing habitat by altering vegetation structure due to their ability to reproduce vastly, and absorb more water than native species.

\section{Banteng Conservation Through Ecotourism Development}

Nowadays, conservation perspective argues that enhancing economic benefits from wildlife through nonconsumptive uses by tourism practices may become one of the significant and effective stimuli to support biodiversity conservation [22]. Meaning, the recent perspectives and approach for Banteng in BNP and APNP are need to be reviewed, with the objectives is improving conservation policy design and objectives that has ability to ensure sustainability of conservation, reducing species threats and enhancing local people benefits for conservation. However, it should be noted that such scenarios should handled carefully, both in planning and implementation. Otherwise, tourism will goes wrong and contributes to the biodiversity extinction.

Respondents argues that the impact of tourism activities to Banteng was predicted numerous, encompasses habitat clearing (i.e.: opening camping site, collecting species or parts of species become souvenir, etc), alien plants species introduction and invasion (i.e.: L. camara, E. inulifolium, C. tora), water and soil pollutions (bottle, plastics and non-degradable materials), animals emigration, changes of activity pattern and reduce animals reproduction ability. There are necessary to discuss the impact of wildlife tourism on wildlife. Meaning, a potential cost derived from tourism activities should be anticipated in tourism practices. Almost all cost potentially lead to wildlife disturbance and extinction.

In case of the promotion of ecotourism programs, respondents argue ecotourism possible to contribute local economic development and forest conservation
(Fig.1). Ecotourism will promoting biodiversity conservation, improving and empowering conservation strategy, improving income for a conservation purpose, improving local society welfare from tourist involvement industry, and improving nature conservation education.

Following the interviews with respondents considering strengths, weaknesses, opportunities and threats aspect of the integration on Banteng into tourism, there is some basic strategy which area possible to promote (Table 1).

These strategy to increase harmony of wildlife conservation and tourism becomes the key to the sustainability and competitiveness of ecotourism in national park. In many regions that have been implementing wildlife tourism, getting support from local people is fundamental to tourism success. This research shows that basically there is significant prospect for Banteng conservation and wildlife tourism development. Nevertheless, as official document findings, the involvement of local people is considered less [6]. In order to create coexistence between tourism and conservation, a management review of park (especially in tourism policy) should be initiate with the objective is achieving successful conservation aims and local people support for conservation.

\section{CONCLUSIONS}

In conclusion, this study has shown that Banteng Bos javanicus populations in a conservation area in Java tend to be decrease. Moreover, threats to population, both socioeconomic and ecological aspects, continuously increase and significantly lead to be responsible factors for species extinction. Over the years, BNP and APNP have been practicing nature-based tourism and creating images that both of them are the best place to observe wildlife, particularly Banteng. Nevertheless, there is a fundamental question related to its sustainability and competitiveness, especially watching wild animals in the wild habitat.

The quality of tourism attraction becomes the basic factors for tourism, particularly where tourism based on resources performance. Banteng and its habitat should be conserved integrally. Several problems occur, mainly because low quality of habitat. In particular, the effort to combat alien species invasion should e carried out with the objectives is allowing grasses and herbs grow. It is fundamentals to support Banteng and other herbivores lives. Asides abundance of grass and herbs for food sources, water, is fundamental sources for wildlife. Issues related water availability and quality 
also need particular attention in the grazing area due to Alas Purwo is known as one of the dry regions in East Java. The limitation of water should be managed appropriately to ensure water stock sustainability for wildlife during the dry season.

\section{ACKNOWLEDGMENT}

The authors wish to thank the Alas Purwo National Park and Baluran National Park and for granting permission to do research in the field. We furthermore thank Biology Department, Brawijaya University staffs for their cooperation and valuable advice throughout the project.

\section{REFERENCES}

1. Stone D, Compost A, Aw M, Severns M (1997) Biodiversity of Indonesia: Tanah Air (Indonesian Heritage). Butterworth-Heineman. Oxford.

2. Whitten T, Soeraatmadja RE, Afiff SA (1996) The Ecology of Java and Bali. The Ecology of Indonesia Series Vol. II. Periplus Edition. Singapore.

3. IUCN - The World Conservation Union (2004) IUCN Red List of Threatened Species. http://www/redlist.org.

4. Hakim L, Leksono AS, Purwaningtyas D, Nakagoshi N (2005) Invasive plants species and the competitiveness of wildlife tourism destination: A case of Sadengan feeding area at Alas Purwo National Park, Indonesia. Journal of International Development and Cooperation.12 (1):35-45.

5. Haryono T (2004) A Report of Alien Species Clearing at Sadengan Feeding Area, Directorate General for Forest Protection and Nature Conservation. Alas Purwo National Park. Banyuwangi

6. TNB (2002a) Five years Management Plan of Baluran $\mathrm{Na}$ tional Park: 2003-2007. Directorate General for Forest Protection and Nature Conservation. Baluran National Park. Banyuwangi.

7. Pudyatmoko S (2004) Does the Banteng (Bos javanicus) have a future in Java? Challenges of the conservation of a large herbivore in a densely populated island. Knowledge Marketplace Reports. The $3^{\text {rd }}$ IUCN World Conservation Congress. Bangkok.

8. Lindsey PA, Alexander RA, du Toit JT, Mills MGL (2005) The potential contribution of ecotourism to African wild dog Lycaon pictus conservation in South Africa. Biological Conservation. 123: 339-348.

9. Reynolds PC, Braithwaite D (2001) Towards a conceptual framework for wildlife tourism. Tourism Management. 22: 31-42.

10. Higginbottom K, Tribe A, Booth R (2003) Contributions of Non-consumptive wildlife tourism to conservation. In: Nature Based Tourism, Environment and Land Management. Buckley, R (eds). CABI Publishing. Wallingford.

11. Dammerman KJ (1929) Preservation of wildlife and natural reserve in the Netherlandsc-Indie. Fourth Pacific Science Congress. Emmink-Weltenvreden. Java.

12. Van Steenis CGGJ (1937) Album van Natuurmonumenten in Netherlandsch-Indie. Vitgegeven door de Netherlandschi-Indische. Vereeningingtot Naturbescherming. Leiden.

13. Alikodra HS (1987) Tanaman eksotik Akasia Acacia nilotica dan masalahnya bagi ekosisitem savanna di Taman Nasional Baluran (An exotic plant Akasia Acacia nilotica and its impact to savanna ecosystem of Baluran National Park). Duta Rimba. 13: 79-80.

14. Hedges S, Tyson MJ (2002) Conflict between endangered species, extinction risk, and the agony of choice: Dholes and Banteng in Java. Abstracts for Risk Assessment and Uncertainty. 16th Annual Meeting Society for Conservation Biology. DIDE and British Ecological Society.

15. Dammerman KJ (1929) Preservation of wildlife and natural reserve in the Netherlandsc-Indie. Fourth Pacific Science Congress. Emmink-Weltenvreden. Java.

16. Garsetiasih R, Alikodra HS, Soekmadi R, Bismark M (2012) Potensi dan produktivitas habitat pakan banteng (Bos javanicus d'alton 1832) di padang perumputan Pringtali dan kebun pantai Bandealit Taman Nasional Meru Betiri Jawa Timur. Jurnal Penelitian Hutan dan Konservasi Alam. 9(2): 113-123.

17. Mardiono D (2010). Penggunaan habitat oleh banteng (Bos javanicus) di Perkebunan Treblasala Banyuwangi. Disertasi Doktoral. Universitas Gadjah Mada. Yogyakarta.

18. Hanberia IF (2011) Karakteristik habitat banteng (Bos javanicus d'Alton 1832) di Taman Nasional Meru Betiri, Jawa Timur. Institute Pertanian Bogor. Bogor.

19. Sunderlin WD, Angelsen A, Resosudarmo DP, Dermawan A, Rianto E (2001) Economic crisis, small farmer well-being, and forest cover change in Indonesia. World Development. 29(5): 767-782.

20. Hedges S, Tyson MJ, Sitompul AF, Kinnaird MF, Gunaryadi D, Aslan (2005) Distribution, status, and conservation needs of Asian elephants (Elephas maximus) in Lampung Province, Sumatra, Indonesia. Biological Conservation. 124: 35-48.

21. Whitten T, Soeraatmadja RE, Afiff SA (1996) The Ecology of Java and Bali. The Ecology of Indonesia Series Vol. II. Periplus Edition. Singapore.

22. Honey M (1999) Ecotourism and Sustainable Development: Who Owns Paradise?. Island Press. Washington DC. 